\title{
Predictive biological markers of systemic lupus erythematosus flares: a systematic literature review
}

\author{
Noémie Gensous ${ }^{1,2}$ (D) Aurélie Marti ${ }^{3}$, Thomas Barnetche ${ }^{4}$, Patrick Blanco ${ }^{1}$, Estibaliz Lazaro ${ }^{1,5}$, Julien Seneschal ${ }^{3}$,
} Marie-Elise Truchetet ${ }^{1,4}$, Pierre Duffau ${ }^{1,2}$, Christophe Richez ${ }^{1,4^{*}}$ and on behalf of the FHU ACRONIM

\begin{abstract}
Background: The aim of this study was to identify the most reliable biomarkers in the literature that could be used as flare predictors in systemic lupus erythematosus (SLE).

Methods: A systematic review of the literature was performed using two databases (MEDLINE and EMBASE) through April 2015 and congress abstracts from the American College of Rheumatology and the European League Against Rheumatism were reviewed from 2010 to 2014. Two independent reviewers screened titles and abstracts and analysed selected papers in detail, using a specific questionnaire. Reports addressing the relationships between one or more defined biological test(s) and the occurrence of disease exacerbation were included in the systematic review.

Results: From all of the databases, 4668 records were retrieved, of which 69 studies or congress abstracts were selected for the systematic review. The performance of seven types of biomarkers performed routinely in clinical practice and nine types of novel biological markers was evaluated. Despite some encouraging results for anti-double-stranded DNA antibodies, anti-C1q antibodies, B-lymphocyte stimulator and tumour necrosis factor-like weak inducer of apoptosis, none of the biomarkers stood out from the others as a potential gold standard for flare prediction. The results were heterogeneous, and a lack of standardized data prevented us from identifying a powerful biomarker.

Conclusions: No powerful conclusions could be drawn from this systematic review due to a lack of standardized data. Efforts should be undertaken to optimize future research on potential SLE biomarkers to develop validated candidates. Thus, we propose a standardized pattern for future studies.
\end{abstract}

Keywords: Systemic lupus erythematosus, Biomarker, Flare, Exacerbation, Systematic review

\section{Background}

Systemic lupus erythematosus (SLE) is a systemic autoimmune disease characterized by a relapsing-remitting course or flare pattern. Flares, defined by an increase in disease activity over a defined amount of time, can be measured using various scores. Flares might lead to substantial organ damage, increasing morbidity and mortality rates and resulting in higher healthcare costs [1].

\footnotetext{
*Correspondence: christophe.richez@chu-bordeaux.fr

Noémie Gensous and Aurélie Marti are equally first authors.

Pierre Duffau and Christophe Richez share co-senior authorship.

'ImmunoConcept, UMR CNRS 5164, Université de Bordeaux, Bordeaux,

France

${ }^{4}$ Department of Rheumatology, Pellegrin Hospital, Place Amélie Raba Léon,

33076 Bordeaux, France

Full list of author information is available at the end of the article
}

Flares are unpredictable in frequency and severity. It is important to identify patients at greater risk for flares to follow them up closely, to make early diagnoses and to initiate rapid treatment or even to consider preventive therapies [2]. Because of a better understanding of SLE pathogenesis, an increasing number of biomarkers have emerged. Close relationships of serum, plasma or urinary profiles with the course of the disease have been explored. Since the 1970s, no investigators have succeeded in identifying a biomarker with the potential to predict efficiently the occurrence of new flares, despite great clinical necessity. We conducted a systematic review of the literature to identify all of the data available on biological SLE flare predictors. 


\section{Methods}

We registered our protocol in PROSPERO (an international prospective registry of systematic reviews) under registration number CRD42015026141. The systematic review was written in accordance with the Preferred Reporting Items for Systematic Reviews and Meta-Analyses (PRISMA) guidelines [3].

\section{Search strategy}

Two investigators (NG and AM) conducted a systematic hand search of the literature in collaboration with a research librarian (EM) using two electronic databases, Medline and EMBASE, from inception to 30 April 2015. In order to cover any research that was not yet published as a manuscript, congress abstracts of the European League Against Rheumatism (EULAR) and the American College of Rheumatology (ACR) from 2010 to 2014 were considered. The search was restricted to the English and French languages and to human subjects. The search keywords in Medline were: "biological markers", "lupus erythematosus, systemic", "severity of illness index", "flare(s)", "exacerbation(s)", "predictive value of tests" and "disease progression". Search terms in EMBASE were: "systemic lupus erythematosus", "biological markers", "flare(s)", "exacerbation(s)", "predictive value of tests" and "disease progression". The exact search strategies are provided in Additional file 1. Abstract lists from the EULAR and the ACR were searched using the keyword "systemic lupus erythematosus". Reference lists of selected papers were hand searched for other relevant publications. We also searched clinicaltrials.gov in May 2015 for unpublished studies on this topic.

\section{Eligibility criteria and study selection}

The two investigators independently screened the titles and abstracts of references, selected articles for full-text review using the inclusion criteria and assessed the methodological quality. Any discrepancies were resolved through consensus. Two supervisors (PD and CR) participated in resolving disagreements.

Interventional studies (randomized or non-randomized, controlled trials) and observational studies (case-control or cohort studies) were included, whereas case reports, literature reviews and editorials were not included. We considered publications involving adults with SLE, addressing the relationships between one or more defined biological test(s) and the occurrence of disease exacerbation. The exclusion criteria were paediatric subjects, other autoimmune diseases and assessment of the role of genetic markers. When duplicate reports were published on the same study, the report with more complete information was extracted.

\section{Data extraction}

The two investigators independently extracted data from each study using a systematic data extraction form (available on request) developed for this specific purpose, including sample size, socio-demographic data and SLE disease characteristics (duration, treatment(s)), follow-up duration and frequency, disease activity measurement (activity indices, definition of flare) and biomarker characteristics (type, measurement method, cut-off values for positivity and increase). After extracting data independently for every study, discrepancies were resolved through consensus.

\section{Data synthesis}

Biomarkers were allocated into one of the following two groups: biomarkers traditionally performed in clinical practice; and experimental and newly developed biological markers. Raw data are available upon request from the first authors.

\section{Results}

From both databases, 4668 records were retrieved, and we added 20 studies identified from the reference lists of papers (Fig. 1). A total of 4126 studies failed to meet the required criteria and 135 full-text articles were retained for complete screening. A total of 69 publications were finally included. No ongoing or unpublished trials relative to this topic were found in the www.clinicaltrials.gov database. The detailed characteristics of the included studies appear in Additional file 2.

\section{Predictors of flares: biomarkers traditionally performed Anti-double-stranded DNA antibodies}

From a 1979 study by Swaak et al. [4], changes in levels of anti-double-stranded DNA antibodies (anti-dsDNA $\mathrm{ab}$ ) during the course of the disease were supposed to be related to SLE exacerbations. Table 1 reviews 28 studies, highlighting the major findings [4-31].

Six studies examined anti-dsDNA ab at baseline without follow-up measurements [5-10]. Four studies failed to show any association between baseline anti-dsDNA ab and subsequent flares [5-8]. Two studies of larger size showed that the elevated baseline antibody level was an independent predictor of moderate-to-severe SLE flares $(\mathrm{HR}=1.83$ (95\% confidence interval (CI) 1.29-2.60)) for any new British Isles Lupus Assessment Group (BILAG) A domain at week 52 [9] or a risk factor only for haematologic flares $(\mathrm{OR}=2.33$ (95\% CI 1.34-4.04), $p=0.0033)$ [10].

An increase in anti-dsDNA ab during the course of the disease was found to precede general flares in nine studies $[4,7,11-17]$, whereas six studies [6, 18-21, 31] failed to prove such an association.

Interestingly, focusing on renal flares, patients with positive anti-dsDNA ab who had persistent or 


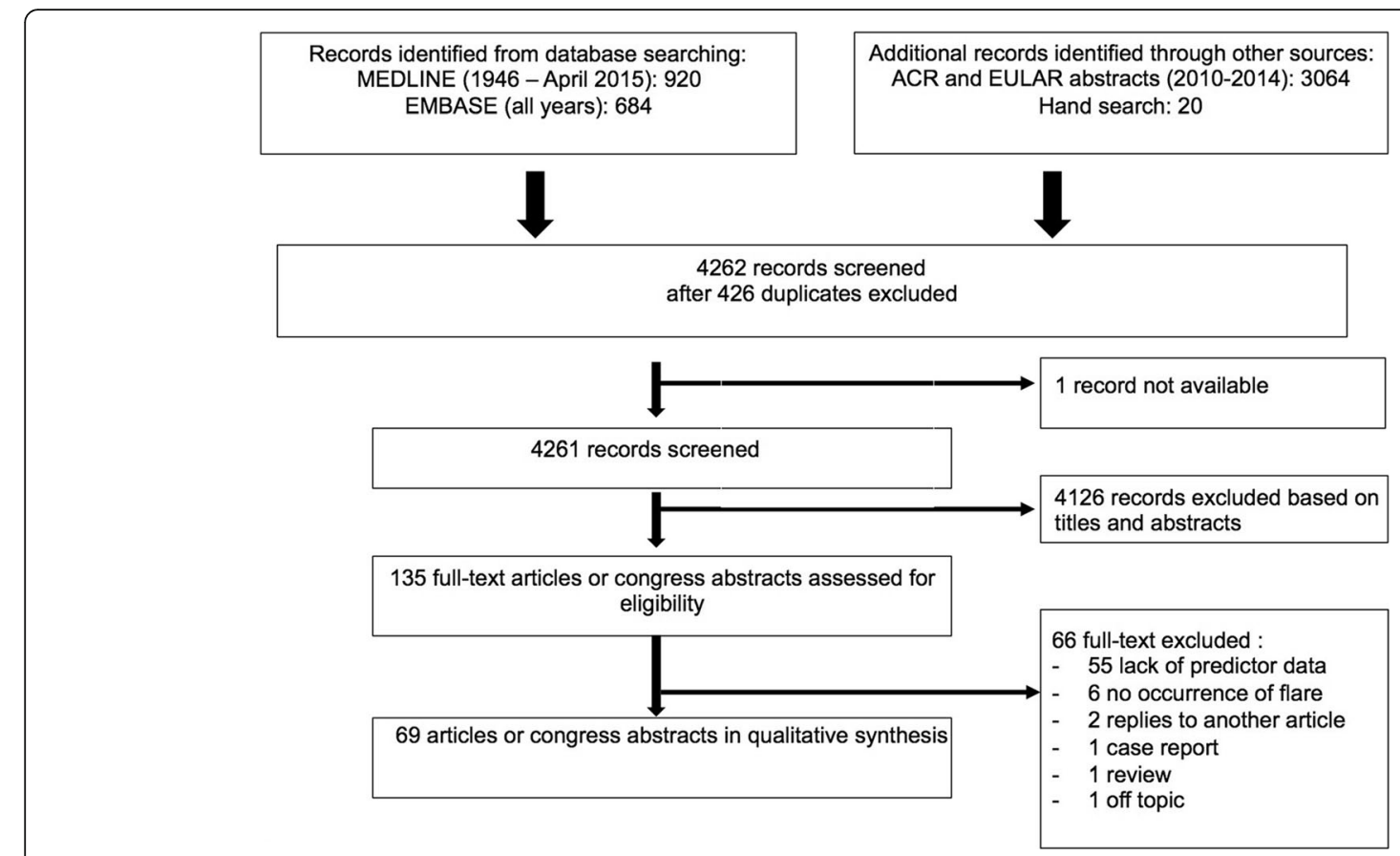

Fig. 1 Study selection process. ACR American College of Rheumatology, EULAR European League Against Rheumatism

increasingly levels were at greater risk for subsequent SLE nephritis [22-24].

The results were expressed in terms of sensitivity, specificity and predictive values in six studies [25-30] (Additional file 3). The conclusions were heterogeneous: sensitivity ranged from $27.7 \%$ [27] to $100 \%$ [30], specificity from $13 \%$ [26] to $89.1 \%$ [28], positive predictive value (PPV) from $4.1 \%$ [28] to 59\% [25] and negative predictive value (NPV) from $67 \%$ [26] to $97.5 \%$ [28].

The choice of a higher anti-dsDNA ab threshold (>300 IU/ml vs $50-300 \mathrm{IU} / \mathrm{ml}$ ) led to higher specificity ( $89.1 \%$ vs $57.1 \%$ for mild/moderate flares) and lower sensitivity (28.4\% vs $51.8 \%$ for mild/moderate flares) [27, 28].

Data concerning the delay between the elevation of anti-dsDNA ab and subsequent flares were not always available. When available, they were heterogeneous, ranging from once per month $[7,9,13,17,24]$ to every 6 weeks $[4,11,12]$, every 3 or 4 months $[6,8,15,16,20$, $22,23,27,28]$, every 6 months $[10,14]$ and up to 1 year or 18 months $[18,26]$. In addition to data concerning delays, those concerning the amount of increase of antidsDNA ab titres were frequently missing $[5,6,8-12,14$, $19,20,22,23]$. The threshold most frequently chosen to define a significant rise was an increase greater than $25 \%$ of the preceding value $[7,13,16,26,29]$.

\section{Complement and complement split products}

Complement and/or complement split products were analysed in 19 studies [6-10, 12, 19, 20, 23, 27, 28, 31-38] (Table 2). The first study assessing the predictivity of complement consumption in SLE flares was conducted by Lloyd and Schur in 1981 [19], and reports the importance of complement depression before exacerbations. Low baseline complement levels could be associated with subsequent SLE flares according to seven studies [7-10, 35, 36,38 ] but these results were not consistent with each other, depending on the complement fraction studied (C3 and/or $\mathrm{C} 4$ and/or $\mathrm{CH} 50$ ): $\mathrm{C} 3$ was found to be associated with flares in four studies $[7,9,10,36]$, whereas $C 4$ was found to be associated in three studies $[8,10,35]$ and $\mathrm{CH} 50$ in two studies $[7,38]$. The occurrence of complement decrease during the course of the disease as revealed by serial measurements was associated with a subsequent flare in two studies [12, 32], whereas three other studies did not prove such an association $[6,20,34]$. Persistently low C3 was predictive of renal flares in two independent studies [10, 23].

Results were expressed in terms of sensitivity, specificity and predictive values in four studies [27, 28, 33, 37] (Additional file 4). The results were heterogeneous: decreased C3 sensitivity ranged from $28.7 \%$ [27] to $45 \%$ [33], and decreased C3 specificity ranged from $63.1 \%$ [27] to $87.5 \%$ [28]. Decreased C4 sensitivity ranged from $19.1 \%$ [28] to $64.0 \%$ [33], and decreased C4 specificity ranged from $45.0 \%$ [33] to $79.0 \%$ [27]. CH50 sensitivity and specificity were evaluated only once, with the respective results of $71.0 \%$ and $29.0 \%$ [33]. Assessments of NPV were always satisfactory, with values superior to 95\% (ranging from $95.8 \%$ for low C4 [28] to $98.3 \%$ for very low C3 [28]). 
Table 1 Predictivity of anti-dsDNA antibodies in SLE flares

\begin{tabular}{|c|c|c|}
\hline Assay & $\begin{array}{l}\text { Number of } \\
\text { patients }(n)\end{array}$ & Findings \\
\hline \multicolumn{3}{|c|}{ Positive results } \\
\hline CLIF & 61 & $\begin{array}{l}67 \% \text { of patients in the group with exacerbations had persistent anti-dsDNA ab } \\
\text { versus } 27 \% \text { in the patient group without exacerbations }\end{array}$ \\
\hline CLIF & 299 & $\begin{array}{l}\text { Increased level at baseline was a risk factor for flare in the haematological } \\
\text { system }(p=0.003)\end{array}$ \\
\hline CLIF & 65 & $\begin{array}{l}\text { Cases, defined as experiencing a surge in anti-dsDNA from } 0 \text { to } 3+/ 4+\text {, or from } \\
1+\text { to } 4+\text {, within a period of less than } 12 \text { months, were more likely to experience } \\
\text { a severe flare than controls (OR } 6.3(\mathrm{Cl} 2.0-19.9), p=0.02)\end{array}$ \\
\hline Farr & 487 & $\begin{array}{l}\text { Frequency of renal flare was lower in patients with sustained reductions in } \\
\text { anti-dsDNA ab ( }>10 \% \text { from baseline levels for at least } 2 / 3 \text { of all observed values) } \\
\text { than in patients with stable or increasing antibody levels }\end{array}$ \\
\hline Farr & 130 & $\begin{array}{l}\text { All } 15 \text { major exacerbations were preceded by an increase of the anti-dsDNA ab levels, } \\
\text { with a doubling time of less than } 6 \text { weeks for } 13 \text { patients. There were four other } \\
\text { patients with an increase in anti-dsDNA levels who did not show any exacerbation }\end{array}$ \\
\hline Farr & 143 & $\begin{array}{l}\text { A continuous increase in the anti-dsDNA ab was found for all patients in the } 24 \\
\text { weeks preceding exacerbations with a doubling time }<10 \text { weeks }\end{array}$ \\
\hline Farr & 78 & $\begin{array}{l}\text { A sharp drop in anti-dsDNA ab, usually preceded by a rise, was related to a serious } \\
\text { exacerbation }\end{array}$ \\
\hline Farr & 151 & $\begin{array}{l}\text { Anti-dsDNA increase started } 4 \text { months prior to the relapse and reached a maximum } \\
\text { at the moment of relapse whereas no fluctuations were observed in patients with } \\
\text { persistently inactive disease }\end{array}$ \\
\hline Farr & 23 & $\begin{array}{l}\text { Presence of anti-dsDNA abs }(>5 \mathrm{IU} / \mathrm{ml}) \text { or increase }(>25 \%) \text { was associated with a } \\
\text { high risk of renal flare }\end{array}$ \\
\hline Farr & 199 & $\begin{array}{l}\text { Patients with anti-dsDNA ab (> } 15 \mathrm{IU} / \mathrm{ml}) \text { had a greater risk of developing } \\
\text { proliferative glomerulonephritis than patients without auto-antibodies }(p=0.048)\end{array}$ \\
\hline ELISA & 70 & $\begin{array}{l}\text { Anti-dsDNA antibodies were detected in } 14 \text { (93.3\%) of } 15 \text { patients with subsequent } \\
\text { lupus nephritis, compared with } 24(72.7 \%) \text { of } 33 \text { patients with active SLE and no } \\
\text { nephritis ( } p=\text { ns) and nine ( } 73 \% \text { ) patients with inactive SLE and no nephritis ( } p=n s \text { ). } \\
\text { Sensitivity for severe lupus nephritis was } 100 \%\end{array}$ \\
\hline
\end{tabular}

Study

Oelzner et al., 1996 [14]

Petri et al., 2009 [10]

Pan et al., 2014 [25]

Linnik et al., 2005 [24]

Swaak et al., 1982 [11]

Swaak et al., 1986 [12]

Swaak et al., 1979 [4]

Coremans et al., 1995 [15]

Matrat et al., 2011 [29]

Cortés-Hernàndez et al., 2004 [22]

Meyer et al., 2009 [30]

Farr and EliA $\quad 48$

CLIF and ELISA 53

CLIF, ELISA and 72

Farr

ELISA and Farr 34

NA

NA

NA

Negative results

$\begin{array}{ll}\text { CLIF } & 27 \\ \text { Farr } & 48 \\ \text { Farr } & 202 \\ \text { Farr } & 120 \\ \text { Farr } & 46 \\ \text { ELISA } & 23\end{array}$

ELISA
All 22 exacerbations were accompanied by changes in anti-dsDNA (> 25\%) in one or both assays

Increase in anti-dsDNA ab predicted flares with M-SLEDAI and M-LAI indices

$89 \%$ of the exacerbations were preceded by a significant increase in anti-dsDNA ab levels (defined as $\geq 2$ titres by the C. luciliae test or $\geq 25 \%$ and at least $100 \mathrm{IU} / \mathrm{ml}$ by the ELISA or $\geq 25 \%$ and at least $30 \mathrm{IU} / \mathrm{ml}$ by the Farr assay)

Patients with rises in IgG class anti-dsDNA ab by ELISA ( $\geq 6 \mathrm{IU} / \mathrm{ml}$ ) or in anti-dsDNA by Farr assay $(\geq 15 \mathrm{IU} / \mathrm{ml})$ had a significantly higher cumulative risk for relapses, with a median time of 2.3 and 2.1 months respectively

Persistently positive anti-dsDNA after cyclophosphamide treatment was an independent predictor of renal flares

The combination of complement C3, C4 and anti-dsDNA antibody is reasonably specific for predicting lupus flares in the preceding 4 weeks

Elevated titres ( $\geq 200 \mathrm{IU} / \mathrm{ml}$ ) at baseline were independent predictors of moderate-to-severe flares at week 52

Serial measurements of anti-dsDNA ab were poor markers of exacerbation. Changes in anti-dsDNA ab failed to correctly predict a change in disease activity

Fluctuations in anti-dsDNA ab were poor predictors of disease exacerbations according to SLEDAI

No consistent association between anti-dsDNA ab positivity and risk of flare defined by SLEDAl

Baseline anti-dsDNA ab failed to predict renal relapses

Anti-dsDNA ab were not predictive of flare
Ho et al., 2001 [17]

ter Borg et al., 1990 [13]

Bootsma et al., 1997 [16]

Mok et al., 2004 [23]

To et al., 2011 [28]

Petri et al., 2013 [9]

Lloyd and Schur, 1981 [19]

Abrass et al., 1980 [18]

Esdaile et al., 1996 [20]

Mirzayan et al., 2000 [6]

El Hachmi et al., 2003 [8]

Steiman et al., 2010 [21] 
Table 1 Predictivity of anti-dsDNA antibodies in SLE flares (Continued)

\begin{tabular}{llll}
\hline Assay & $\begin{array}{l}\text { Number of } \\
\text { patients }(n)\end{array}$ & Findings & Study \\
\hline Farr and CLIF & 73 & No difference between the patients who flared and the patients who did not & Walz LeBlanc et al., 1994 [31] \\
NA & 57 & $\begin{array}{l}\text { Percentage of patients who had positive anti-dsDNA ab at the time of the } \\
\text { diagnosis was not higher in patients with a subsequent exacerbation }\end{array}$ & Tomioka et al., 2008 [7] \\
NA & 110 & Anti-dsDNA ab were not identified as a predictor of flare & Swaak et al., 1989 [5] \\
NA & 218 & Anti-dsDNA lacks sensitivity in predicting serosal and neuropsychiatric lupus flares & To et al., 2011 [27] \\
\hline
\end{tabular}

anti-dsDNA ab anti-double-stranded DNA antibodies, CI confidence interval, CLIF Crithidia luciliae immunofluorescence, ELISA enzyme-linked immunosorbent assay, EliA automated enzyme fluoroimmunoassay, M-LAI Modified Lupus Activity Index, M-SLEDAI Modified Systemic Lupus Erythematosus Disease Activity Index, NA not available, ns not significant, OR odds ratio, SLE systemic lupus erythematosus, SLEDAI Systemic Lupus Erythematosus Disease Activity Index

Some complement split products $(\mathrm{C} 3 \mathrm{a}, \mathrm{C} 4 \mathrm{~d}, \mathrm{Ba}, \mathrm{Bb}$, SC5b9) were found to be informative in predicting lupus flares, particularly C3a (1-2 months prior to disease flare, C3a levels increased significantly for all 10 patients studied who experienced flares later), C4d (highest sensitivity $86.0 \%$ ) and $\mathrm{Bb}$ (highest specificity $81.0 \%$ ) [32, 33].

\section{Anti-C1q antibodies}

Authors reported very good NPV for lupus nephritis [30, 39, 40], ranging from $97.0 \%$ (95\% CI 88.0-99.0\%) [40] to $100.0 \%[30,39]$. For instance, in one study, none of the 50 patients with negative anti-C1q antibodies developed any sign of renal involvement during follow-up (median duration 24 months, range 1-60 months) [39]. NPV was less impressive in one study (70.0\%) [29] (Table 3). PPV was always unsatisfactory (ranging from 50 to $56 \%$ ). The high NPV of anti-C1q antibodies, especially for nephritis $[30,39]$, seemed to be of particular interest, suggesting that the occurrence of severe nephritis is quite improbable in the absence of anti-C1q antibodies. These results seemed promising for clearly identifying patients who are at low risk for flares or renal involvement.

\section{Anti-nuclear antibodies, antibodies against extractable nuclear antigens and antibodies against nucleosomes}

Antibodies against extractable nuclear antigens (antiENA) and anti-nucleosomes were studied in eight reports $[5,6,9,22,36,41-43]$ (Table 4). Associations between anti-ENA and the occurrence of a flare were found in six studies, with the important limitation that these results were reported in only one study each, and none of them has been reproduced: anti-nuclear antibodies (ANA) [6], baseline anti-ENA [36], anti-Sm [5, 9], anti-histone [22] and anti-nucleosome [42]. No correlations with disease activity were found with anti-Ro [41, 43], anti-La, anti-Sm and anti-ribonucleoprotein (antiRNP) [41]. Repetition of the measurement of anti-ENA antibodies appeared not to be useful in assessing disease activity in SLE, and the determination of anti-ENA antibody profiles should be limited to the diagnosis period.

\section{Circulating immune complexes}

Two reports [18, 19], published in 1980 and 1981, studied the associations of circulating immune complexes with the occurrence of flares. In the study by Abrass et al. [18], circulating immune complexes were measured by both solid-phase (SC1q) and fluid-phase C1q (FC1q) binding assays. An increase in $\mathrm{SClq}$ binding assay results correctly predicted a change in the manifestations of SLE $82 \%$ of the time. In comparison, changes in FC1q binding assay failed to predict a change in disease activity correctly. In the other study, immune complexes were measured by $\mathrm{C} 1 \mathrm{q}$ binding assay $\mathrm{C} 1 \mathrm{qBA}$ and $\mathrm{ADCC}$ (antibody-dependent cell-mediated cytotoxicity) inhibition assay [19]. Only $50 \%$ of the patients had increased levels of C1qBA prior to clinical exacerbation. These tests are no longer used in clinical practice.

\section{Erythrocyte sedimentation rate and C-reactive protein}

No statistically significant association between change in erythrocyte sedimentation rate (ESR) between two visits and a future change in disease activity was found [38, 44]. In another study, ESR elevations were associated with flares [6].

Petri et al. [9] demonstrated that, according to univariate analysis, elevated C-reactive protein (CRP) at baseline predicted SLE flares by three indices (BILAG, Safety of Estrogens in Lupus Erythematosus National Assessment-Systemic Lupus Erythematosus Disease Activity Index (SELENA-SLEDAI), SLEDAI Flare Index (SFI)) during the course of the study, but this association was no longer persistent in multivariate analysis.

\section{Predictors of flares: experimental and newly developed biological markers, a new hope? Cytokines, chemokines and their receptors}

Several cytokines and chemokines or their soluble receptors were examined in 14 studies [9, 45-57] (Table 5). The ability of B-lymphocyte stimulating factor (BLyS), also known as B-cell activating factor from the TNF family (BAFF), to predict a subsequent SLE flare was dismissed in two studies $[47,52]$ but confirmed in two others $[9,48]$. Three studies revealed an increase in the plasma levels of soluble IL-2R 
Table 2 Predictivity of complement in SLE flares

\begin{tabular}{|c|c|c|c|}
\hline Complement fraction(s) & $\begin{array}{l}\text { Number of } \\
\text { patients }(n)\end{array}$ & Findings & Study \\
\hline \multicolumn{4}{|l|}{ Positive results } \\
\hline $\mathrm{C} 3, \mathrm{C} 4$ and $\mathrm{CH} 50$ & 57 & $\begin{array}{l}\text { Increased incidence of exacerbation in patients with } \\
\text { decreased level of } \mathrm{C} 3 \text { or } \mathrm{CH} 50\end{array}$ & Tomioka et al., 2008 [7] \\
\hline $\mathrm{C} 3$ and $\mathrm{C} 4$ & 562 & $\begin{array}{l}\text { Low C3 level }(<900 \mathrm{mg} / \mathrm{L}) \text { was an independent predictor } \\
\text { of a severe SFI flare }\end{array}$ & Petri et al., 2013 [9] \\
\hline $\mathrm{C} 3$ and C4 & 299 & $\begin{array}{l}\text { Low C3 and C4 were risk factors for a later A or B flare in } \\
\text { the mucocutaneous, renal and haematologic systems }\end{array}$ & Petri et al., 2009 [10] \\
\hline C3 & 32 & $\begin{array}{l}\text { Low baseline serum C3 }(<900 \mathrm{mg} / \mathrm{L}) \text { was a predictor for } \\
\text { shorter time to flare }\end{array}$ & Ng et al., 2007 [36] \\
\hline $\mathrm{C} 3$ and $\mathrm{C} 4$ & 46 & $\begin{array}{l}\text { Baseline C4 titres were low }(<10 \mathrm{mg} / \mathrm{dl}) \text { in a significantly } \\
\text { higher percentage of relapsing patients }\end{array}$ & El Hachmi et al., 2003 [8] \\
\hline $\mathrm{C} 3$ and $\mathrm{C4}$ & 145 & $\begin{array}{l}\text { C4 level }(<11 \mathrm{mg} / \mathrm{dl}) \text { was a significant prognostic factor } \\
\text { for renal flares }\end{array}$ & Illei et al., 2002 [35] \\
\hline $\mathrm{CH} 50$ & 60 & CH50 level was an independent predictor of lupus flares & Viallard et al., 2001 [38] \\
\hline $\mathrm{C} 1 \mathrm{q}, \mathrm{C} 3, \mathrm{C} 4, \mathrm{C} 5$ and $\mathrm{C} 9$ & 143 & $\begin{array}{l}\text { Decrease of C4, followed by decreases of C1q and C3 levels } \\
\text { ( }<40 \% \text { of normal values), started } 25 \text { to } 20 \text { weeks before } \\
\text { renal involvement }\end{array}$ & Swaak et al., 1986 [12] \\
\hline $\mathrm{C} 3 \mathrm{a}, \mathrm{C} 5 \mathrm{a}, \mathrm{C} 3$ and $\mathrm{C} 4$ & 40 & $\begin{array}{l}\text { C3a levels rose significantly (>200 ng/ml) 1-2 months prior } \\
\text { to flare }\end{array}$ & Hopkins et al., 1988 [32] \\
\hline C3 & 189 & $\begin{array}{l}\text { Persistently low C3 level was a predictor of nephritic } \\
\text { renal flares }\end{array}$ & Mok et al., 2004 [23] \\
\hline $\mathrm{C} 1 \mathrm{q}, \mathrm{C} 3, \mathrm{C} 4$ & 27 & $\begin{array}{l}\text { When patients were clinically active, mean values of } \mathrm{C} 1 \mathrm{q}, \mathrm{C} 4 \\
\text { and } \mathrm{CH} 50 \text { were the lowest obtained for these markers }\end{array}$ & Lloyd and Schur, 1981 [19] \\
\hline $\mathrm{C} 3$ and $\mathrm{C} 4$ & 71 & $\begin{array}{l}\text { Lower C4 levels }(<12 \mathrm{mg} / \mathrm{dl}) \text {, but not C3 levels, significantly } \\
\text { predicted renal flares }\end{array}$ & Birmingham et al., 2010 [37] \\
\hline $\mathrm{C} 3$ and $\mathrm{C} 4$ & 218 & $\begin{array}{l}\text { For renal flares: low C3 }(0.5-0.74 \mathrm{~g} / \mathrm{L}) \text {, sensitivity } 34.8 \% \text {, specificity } \\
63.1 \% \text {; low C4 (0.1-0.13 g/L), sensitivity } 19.4 \% \text {, specificity } 79 \%\end{array}$ & To et al., 2011 [27] \\
\hline $\mathrm{C} 3$ and $\mathrm{C} 4$ & 218 & $\begin{array}{l}\text { For severe flares: low C3 (0.5-0.74 g/L), sensitivity 29.2\%, specificity } \\
63 \% \text {, PPV } 2.3 \% \text {, NPV 96.7\%; low C4 (0.1-0.13 g/L), sensitivity } 19.2 \% \text {, } \\
\text { specificity } 79 \% \text {, PPV 2.8\%, NPV } 96.0 \%\end{array}$ & To et al., 2011 [28] \\
\hline $\begin{array}{l}\mathrm{C} 3, \mathrm{C} 4, \mathrm{CH} 50 \text { and complement } \\
\text { split products: } \mathrm{Ba} \text {, Bb; } \mathrm{C} 4 \mathrm{~d} \text {; SC5b-9 }\end{array}$ & 86 & $\begin{array}{l}\text { Most sensitive marker of flare: elevated } C 4 \mathrm{~d}(>8.5 \mathrm{mg} / \mathrm{ml}) \text {. Highest } \\
\text { specificity and greatest predictive value for flare: elevated Bb } \\
(>1.2 \mathrm{mg} / \mathrm{ml})\end{array}$ & Buyon et al., 1992 [33] \\
\hline \multicolumn{4}{|l|}{ Negative results } \\
\hline $\mathrm{C} 3, \mathrm{C} 4$ and $\mathrm{C} 1 \mathrm{q}$ & 202 & Fluctuations were poor predictors of exacerbations & Esdaile et al., 1996 [20] \\
\hline $\mathrm{C} 3$ and $\mathrm{C} 4$ & 53 & $\begin{array}{l}\text { Decreasing complement levels did not precede changes in } \\
\text { disease activity }\end{array}$ & Ho et al., 2001 [34] \\
\hline $\mathrm{CH} 50$ & 120 & $\begin{array}{l}\text { No consistent association of complement titre with flares in the } \\
\text { subsequent year }\end{array}$ & Mirzayan et al., 2000 [6] \\
\hline $\mathrm{C} 3, \mathrm{C} 4$ and $\mathrm{CH} 50$ & 73 & $\begin{array}{l}\text { No difference between patients who flared and patients who } \\
\text { did not }\end{array}$ & Walz LeBlanc et al., 1994 [31] \\
\hline
\end{tabular}

NPV negative predictive value, PPV positive predictive value, SFI SLE Flare Index, SLE systemic lupus erythematosus

or $\mathrm{sCD} 25$ (which is the alpha chain of IL-2R) prior to disease exacerbation $[52,55,57]$, while another study revealed a higher expression of CD25 on the surface of circulating lymphocytes [56]. The results concerning other cytokines, chemokines and receptors were single reports; consequently, generalization of these data did not seem suitable.

\section{Expression of specific markers by $T$ cells}

Five studies [38, 55-58] assessed the relationship between the expression of specific antigens or specific transcription factors by $\mathrm{T}$ cells and disease flares. Markers testifying to the activation of $\mathrm{T}$ lymphocytes were the most studied, by measurement of serum levels of specific activation antigens or by flow cytometry. Levels of sCD27 increased before exacerbation in the three patients studied [55]. HLA-DR expression by $\mathrm{CD}^{+} \mathrm{T}$ lymphocytes [38] or by $\mathrm{CD}^{+}$ lymphocytes [56] appeared to be associated with the occurrence of a lupus flare. Expression of CD25 was also considered a marker of lymphocyte activation, and the results achieved were presented in the preceding section [56]. 
Table 3 Predictivity of anti-C1q antibodies in SLE flares

\begin{tabular}{lll}
\hline Number of patients $(n)$ & Findings & Study \\
\hline 68 & For renal flares: sensitivity 71\%, specificity 92\%, PPV 50\%, NPV 97\% & Siegert et al., 1993 [40] \\
151 & 10 of 14 patients who developed proliferative nephritis had significant increases in anti-C1q level & Coremans et al., 1995 [15] \\
151 & NPV 100\% for nephritis & Marto et al., 2005 [39] \\
70 & For severe lupus nephritis: sensitivity 100\%, specificity 95.7\%, PPV 50\%, NPV 100\% & Meyer et al., 2009 [30] \\
23 & For renal flares: sensitivity 75.7\%, specificity 84\%, PPV 56\%, NPV 70\% & Matrat et al., 2011 [29] \\
\hline
\end{tabular}

All anti-C1q antibodies were measured using enzyme-linked immunosorbent assays

NPV negative predictive value, PPV positive predictive value, SLE systemic lupus erythematosus

Another study examined the expression of the specific transcription factor FoxP3 in different subsets of CD4 ${ }^{+}$ $\mathrm{T}$ cells (naïve T-regulatory (Treg) cells, effector Treg cells and $\mathrm{FoxP}^{+}$non-Treg cells) in a small cohort of SLE patients [58]. Most of the patients who developed flares had anomalies in FoxP3 ${ }^{+} \mathrm{CD} 4{ }^{+}$T-cell subsets before flares (the most prevalent anomaly observed before flares was an increase in FoxP3 ${ }^{+}$non-Treg cells), while those who maintained the absence of anomalies did not develop flares.

\section{Markers of endothelial activation}

Three cellular adhesion molecules, required for cell-to-cell interactions, were evaluated in two studies [59, 60]: the results were contradictory regarding soluble vascular cell adhesion molecule-1 (sVCAM-1) in the two reports and were clearly negative for soluble intercellular adhesion molecule-1 (sICAM-1) and soluble E-selectin (sE-selectin).

\section{Urinary markers}

Seven records studied biomarkers in the urine of SLE patients [61-67]. Five molecules, namely tumour necrosis factor-like weak inducer of apoptosis (TWEAK), macrophage colony-stimulating factor (M-CSF), neopterin, regulated on activation, normal T-cell expressed and secreted
(RANTES) and urinary neutrophil gelatinase-associated lipocalin (uNGAL), were measured in urine by ELISA (or by reverse-phase high-performance liquid chromatography for neopterin) in five studies [63-67]. These markers were all positively correlated with subsequent SLE renal flares. TWEAK seemed of particular interest because the results were consistent through three different studies, and this marker is considered a potentially promising therapeutic target for lupus nephritis [68]. While other reports evaluated single molecules measured in urine, two studies assessed the expression of transcription factors or the transcriptional expression of cytokines [61, 62]. One study evaluated the expression of T-bet by urinary sediment cells and revealed that a high urinary T-bet expression level was an independent predictor of a lupus flare [61]. In the other study, a significant increase was found in the mRNA levels of monocyte chemotactic protein (MCP)-1 and FoxP3 before disease flares, along with decreases in IL-17 and GATA-3 [62].

\section{Other experimental biomarkers}

In 1991, ter Borg et al. [69] evaluated the ability of anti$70-\mathrm{kDa}$ and anti-A polypeptides antibodies to predict SLE flares but failed.

Table 4 Predictivity of anti-ENA in SLE flares

\begin{tabular}{|c|c|c|c|}
\hline Biomarker(s) & $\begin{array}{l}\text { Number of } \\
\text { patients }(n)\end{array}$ & Findings & Study \\
\hline Anti-Sm ab, ANA & 110 & $\begin{array}{l}\text { Presence of anti-Sm ab at baseline was found at a higher incidence in } \\
\text { patients developing exacerbation(s) }\end{array}$ & Swaak et al., 1989 [5] \\
\hline ANA & 120 & ANA titre was associated with flares in the subsequent year & Mirzayan et al., 2000 [6] \\
\hline $\begin{array}{l}\text { ANA, anti-nucleosome } \\
\text { and anti-histone } a b\end{array}$ & 199 & $\begin{array}{l}\text { Patients with anti-histone ab ( } \geq 3 \text { SDs above control mean) at baseline } \\
\text { had a higher risk of developing lupus nephritis }\end{array}$ & Cortes-Hernandez et al., 2004 [22] \\
\hline Anti-nucleosome ab & 21 & $\begin{array}{l}\text { Time to first flare was significantly correlated with the presence of } \\
\text { anti-nucleosome and high anti-nucleosome ab titres }\end{array}$ & $\mathrm{Ng}$ et al., 2006 [42] \\
\hline Anti-ENA & 32 & Baseline anti-ENA was an independent predictor of flare & Ng et al., 2007 [36] \\
\hline ANA, anti-Sm ab & 562 & Anti-Sm positivity ( $\geq 15$ units $/ \mathrm{ml}$ ) at baseline predicted flares & Petri et al., 2013 [9] \\
\hline Anti-Ro & 47 & Fluctuations of anti-Ro/SS-A ab levels were not predictive of flares & Praprotnik et al., 1999 [43] \\
\hline $\begin{array}{l}\text { Anti-Ro, anti-La, anti-Sm } \\
\text { and anti-RNP ab }\end{array}$ & 45 & $\begin{array}{l}\text { Fluctuations of anti-Ro, anti-La, anti-Sm and anti-RNP were not } \\
\text { associated with flares }\end{array}$ & Agarwal et al., 2009 [41] \\
\hline
\end{tabular}

$a b$ antibody, ANA anti-nuclear antibodies, anti-RNP anti-ribonucleoprotein, anti-ENA anti-extractable nuclear antigen, SD standard deviation, SLE systemic lupus erythematosus 
Table 5 Predictivity of cytokines and chemokines in SLE flares

\begin{tabular}{|c|c|c|c|}
\hline Cytokines or chemokines & $\begin{array}{l}\text { Number of } \\
\text { patients }(n)\end{array}$ & Findings & Study \\
\hline BAFF/BLyS & 42 & $\begin{array}{l}\text { Changes in BAFF levels were unrelated to } \\
\text { disease flares }\end{array}$ & $\begin{array}{l}\text { Becker-Merok et al., } \\
2006 \text { [47] }\end{array}$ \\
\hline BAFF/BLyS & 245 & $\begin{array}{l}\text { Increase in BLyS level was associated with the occurrence of mild-to- } \\
\text { moderate flares }\end{array}$ & Petri et al., 2008 [48] \\
\hline BAFF/BLyS & 562 & Baseline BLyS level independently predicted flare & Petri et al., 2013 [9] \\
\hline $\begin{array}{l}\text { BLyS, APRIL and } 50 \text { analytes: innate } \\
\text { and adaptive cytokines, chemokines } \\
\text { and soluble TNFR superfamily members }\end{array}$ & 28 & $\begin{array}{l}\text { Patients with impending flare had significant } \\
\text { alterations in the levels of } 27 \text { soluble mediators } \\
\text { at baseline }\end{array}$ & Munroe et al., 2014 [52] \\
\hline $\begin{array}{l}\text { CCL2 (MCP-1), CCL19 (MIP-3B), } \\
\text { CXCL10 (IP-10) }\end{array}$ & 267 & $\begin{array}{l}\text { Patients with high baseline chemokine levels were } \\
\text { at increased risk for flares }\end{array}$ & Bauer et al., 2009 [49] \\
\hline CXCL2, CXCL10 & 25 & $\begin{array}{l}\text { High CXCL10 and CXCL2 were predictive of increased } \\
\text { disease activity }\end{array}$ & Andrade et al., 2012 [50] \\
\hline$I L-2 R$ & 26 & $\begin{array}{l}\text { Activation of T cells occurs prior to clinical disease } \\
\text { activity }\end{array}$ & Spronk et al., 1996 [56] \\
\hline$S I L-2 R$ & NA & $\begin{array}{l}\text { Levels of sIL-2R rose significantly up to the moment } \\
\text { of maximal disease activity }\end{array}$ & Spronk et al., 1994 [57] \\
\hline sCD25 & 3 & $\begin{array}{l}\text { Levels of sCD25 increased preceding periods of } \\
\text { exacerbations }\end{array}$ & Swaak et al., 1995 [55] \\
\hline $\begin{array}{l}\text { IFN-a, IFN-y-inducible protein } 1 \text { and } \\
\text { sialic acid-binding Ig-like lectin } 1\end{array}$ & 79 & $\begin{array}{l}\text { None of the investigated biomarkers was a predictive } \\
\text { variable for flares }\end{array}$ & Rose et al., 2013 [51] \\
\hline Soluble IL-7 receptor (sIL-7R) & 105 & High sIL-7R levels associated with renal flares & $\begin{array}{l}\text { Lauwerys et al., } 2014 \\
\text { [53] }\end{array}$ \\
\hline IL1-RA, TNFRI & 41 & $\begin{array}{l}\text { Patients who flared had higher baseline plasma levels } \\
\text { of IL-1RA and TNFRI }\end{array}$ & $\begin{array}{l}\text { Guthridge et al., } 2014 \\
\text { [54] }\end{array}$ \\
\hline
\end{tabular}

$\overline{A P R I L}$ a proliferation-inducing ligand, BAFF B-cell activating factor, BLyS B-lymphocyte stimulator, $C C L$ chemokine ligand, $C X C L$ chemokine (C-X-C motif) ligand, $s$ soluble, SLE systemic lupus erythematosus, TNFR tumour necrosis factor receptor type

Plasma adiponectin did not change significantly before flares, whereas longitudinal testing revealed that urine adiponectin increases began in the 2 months prior to renal flares [70].

Plasma cell peaks $\left(\mathrm{CD} 27^{++}, \mathrm{CD} 20^{-}\right.$cells $)$preceded the increase in disease activity [71].

Patients with circulating anti-dsDNA ab-secreting cells had significantly lower cumulative rates for remaining disease flare-free than patients without these cells in the circulation [72]. Nearly all of the patients with circulating anti-dsDNA ab-secreting cells relapsed within 12 months.

\section{Discussion}

Despite the clinical interest in and numerous publications on biomarkers in SLE, there is no validated and widely accepted biomarker for flare prediction in SLE to date. In this systematic review, none of the newly studied biomarkers stood out, and the routinely performed biomarkers appeared to be deceiving, with contradictory results. Data concerning some biomarkers, such as antiC1q antibodies, BLyS or TWEAK, seemed promising and could be useful in identifying SLE patients who are at high risk for flares and especially at high risk for renal disease, but these results require confirmation in larger studies. Clinicians must be aware that, at this time, none of these biological markers is completely reliable in diagnosing exacerbations, and none of them can be considered a serologic gold standard. The use of some laboratory parameters, such as anti-dsDNA ab, complement and anti-C1q, and their close follow-up are still considered the most powerful tools in predicting disease flares, even if limited. Thus, they are included in the current EULAR recommendations [73] and should not be abandoned easily.

This systematic review was, to the best of our knowledge, the first aiming to compile all of the available data on biomarkers predicting SLE flares. The strengths of this study included a comprehensive review of the reports on predictive biomarkers in SLE with well-defined inclusion criteria, performed with the help of a research librarian and with data extraction performed by two independent reviewers.

Our conclusions must be considered in the presence of possible limitations. One of the main limitations of this work was the high heterogeneity between the study designs, reflecting the heterogeneity of the disease itself. The best study design to emphasize the predictivity of a biomarker is a prospective study. Nevertheless, 14 studies were retrospective and might have been biased. 
Another design issue was follow-up frequencies: patients were either observed monthly $[13,17]$ or every 3 months $[20,22]$. The risk of missing an increase in antibody levels is negligible with monthly measurements. Therefore, studies with monthly follow-ups might detect correlations more often. However, the clinical utility of monthly measurements has not yet been assessed, and the economic burden of close monitoring must be justified. The study populations were heterogeneous by ethnicity, time from diagnosis, sample size, treatment and disease activity at baseline. Above all, the heterogeneity in flare definitions and disease activity measurements was the most important limiting factor and could prevent comparison of different studies. The concept of a flare in this disease is very complex, and there is no universally accepted definition to date. The absence of a standardized definition complicates the interpretation and comparison of findings. Clinicians use many indices (SLEDAI, SELENA-SLEDAI, BILAG, Physician Global Assessment (PGA), SFI, European Consensus Lupus Activity Measurement (ECLAM)), which, although valid and sensitive, do not evaluate the disease in the same manner [74]. None of them has emerged yet as a gold standard, which led to inconsistent results depending on the index used [17]. Flare rates, which are different between reports, can also vary within a report depending on the index used [9]. The choice to include different degrees of severity (mild/moderate or severe) might have modified the total number of flares and thus affected the sensitivity and specificity of biomarkers. Concerning the biomarkers themselves, the assay techniques could first lead to heterogeneity due to their different performance characteristics. The sensitivity, specificity, PPV and NPV were different if the Farr assay, C. luciliae assay or ELISA was used for measuring anti-dsDNA ab $[25,26$, 29, 30]. The Farr radioimmunoassay is believed to detect high-avidity antibodies, C. luciliae assays detect antibodies of intermediate avidity and ELISA detects both high-avidity and low-avidity antibodies [75, 76]. We could not determine with certainty whether one of these assays is more performant than another due to the low number of studies. The results can also vary according to the class of Ig considered for the measurement of anti-dsDNA ab (positive results with IgG and negative results with IgM) [16], which could explain, in part, the discrepancies in the results between studies. Moreover, the use of plasma or serum samples for the assay can be important: some authors believe that it is necessary to use plasma instead of serum to measure anti-dsDNA ab to avoid the possible binding of antibodies to DNA from disrupted blood cells [76]. Finally, the threshold levels chosen for positive test results could also be a source of discrepancy. To increase the ability of biomarkers to predict flares, some authors have combined traditional ones. Values (especially PPV) obtained in this manner were often higher than those of each marker obtained separately [28-30], but these data are scarce. Development of prediction models for outcomes of the disease using multiple biomarkers that can be measured at the same time with commercial kits would actually be of great interest [77] and a study of the transcriptome profile could also be promising [78]. Last but not least, it is of particular interest to underline the concept of "serologically active, clinically quiescent" (SACQ) SLE, with discordance between clinical and serologic features, which adds another level of complexity for the prediction of flare in some patients. A large international task force reached recent consensus on the definition of SACQ, which corresponds to the presence of antidsDNA ab and/or hypocomplementemia [79]. In this group of patients, fluctuations in anti-dsDNA ab and complement levels cannot predict flares and no consensus was obtained by the task force regarding the definition of remission in those patients [79].

Clinicians need more data to help them to choose the correct biomarker or biomarker combination to predict flares, and the quest for a predictive marker of disease activity should be a major focus of SLE clinical research. With the advent of personalized medicine, with an increasing number of targeted therapies, reliable noninvasive predictors of flares are of great interest. There is a need to conduct prospective studies with standardized guidelines about severity indices and flare definitions to validate potentially relevant biomarkers and to bring them into the field of daily clinical practice, in the same manner as has been performed for therapeutic trials [73].

To homogenize study patterns, we propose conducting multicentre, longitudinal, prospective, controlled studies, including patients with SLE who fulfil the revised ACR criteria and who are ethnically diverse. The most appropriate SLE flare index must be chosen among BILAG, SLEDAI or ECLAM, as encouraged by EULAR recommendations [73], and only one score should be used. Follow-up visits should occur every 3 months over at least 3 years. Thresholds for increases and decreases in each biological marker should be defined clearly. Biomarkers should be validated with assessments of sensitivity, specificity and predictive values. Candidate biomarkers with promising results in small patient cohorts must to be validated in large populations. Biomarker panels must be developed.

\section{Conclusions}

No conclusions could be drawn from this systematic review due to the lack of standardized data. Efforts should be undertaken to optimize future research on potential 
SLE biomarkers to develop validated candidates. Thus, we propose a standardized pattern for future studies.

\section{Additional files}

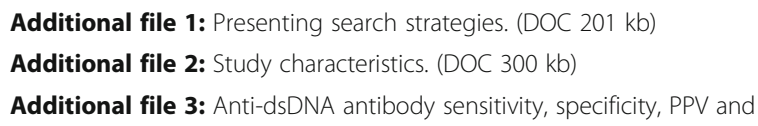

Additional file 4: Complement sensitivity, specificity, PPV and NPV. (DOC $47 \mathrm{~kb}$ )

\begin{abstract}
Abbreviations
ACR: American College of Rheumatology; ANA: Anti-nuclear antibodies; AntidsDNA ab: Anti-double-stranded DNA antibodies; Anti-ENA: Antibodies against extractable nuclear antigens; Anti-RNP: Anti-ribonucleoprotein; BAFF: B-cell activating factor from the TNF family; BILAG: British Isles Lupus Assessment Group; BLyS: B-lymphocyte stimulating factor; CRP: C-reactive protein; ECLAM: European Consensus Lupus Activity Measurement; ESR: Erythrocyte sedimentation rate; EULAR: European League Against Rheumatism; MCP: Monocyte chemotactic protein; M-CSF: Macrophage colony-stimulating factor; NPV: Negative predictive value; PGA: Physician Global Assessment; PPV: Positive predictive value; PRISMA: Preferred Reporting Items for Systematic Reviews and Meta-Analyses; RANTES: Regulated on activation, normal T-cell expressed and secreted; SACQ: Serologically active, clinically quiescent; SELENA-SLEDAI: Safety of Estrogens in Lupus Erythematosus National Assessment-Systemic Lupus Erythematosus Disease Activity Index; sE-selectin: Soluble E-selectin; sICAM1: Soluble intercellular adhesion molecule-1; SLE: Systemic lupus erythematosus; sVCAM-1: Soluble vascular cell adhesion molecule-1; Treg: Tregulatory; TWEAK: Tumour necrosis factor-like weak inducer of apoptosis; UNGAL: Urinary neutrophil gelatinase-associated lipocalin
\end{abstract}

\section{Acknowledgements}

The authors would like to acknowledge E. Mouillet, a research librarian, and H. Maisonneuve for their advice and support.

\section{Funding}

This research did not receive any specific grant from funding agencies in the public, commercial or not-for-profit sectors.

\section{Availability of data and materials}

The data analysed during the current study are available from the corresponding author on reasonable request.

\section{Authors' contributions}

NG and AM contributed equally to this work. All authors were involved in drafting the article or revising it critically for important intellectual content. All authors approved the final manuscript. NG, AM, TB, PB, EL, JS, M-ET, PD and $C R$ were responsible for study conception and design. NG and $A M$ were responsible for acquisition of data. NG, AM, TB, PB, EL, JS, M-ET, PD and CR were responsible for analysis and interpretation of data.

\section{Ethics approval and consent to participate}

Not applicable.

\section{Consent for publication \\ Not applicable.}

\section{Competing interests}

The authors declare that they have no competing interests.

\section{Publisher's Note}

Springer Nature remains neutral with regard to jurisdictional claims in published maps and institutional affiliations.

\section{Author details}

'ImmunoConcept, UMR CNRS 5164, Université de Bordeaux, Bordeaux, France. ${ }^{2}$ Department of Internal Medicine and Clinical Immunology, Saint-Andre Hospital, Bordeaux, France. ${ }^{3}$ Department of Dermatology, Saint-Andre Hospital, Bordeaux, France. ${ }^{4}$ Department of Rheumatology, Pellegrin Hospital, Place Amélie Raba Léon, 33076 Bordeaux, France. ${ }^{5}$ Department of Internal Medicine and Infectious Diseases, Haut-Leveque Hospital, Pessac, France.

Received: 27 April 2017 Accepted: 25 September 2017

Published online: 24 October 2017

\section{References}

1. Zhu TY, Tam L-S, Lee WW-Y, Lee KK-C, Li EK. The impact of flare on disease costs of patients with systemic lupus erythematosus. Arthritis Rheum. 2009; 61:1159-67.

2. Tseng C-E, Buyon JP, Kim M, Belmont HM, Mackay M, Diamond B, et al. The effect of moderate-dose corticosteroids in preventing severe flares in patients with serologically active, but clinically stable, systemic lupus erythematosus: findings of a prospective, randomized, double-blind, placebo-controlled trial. Arthritis Rheum. 2006;54:3623-32.

3. Moher D, Liberati A, Tetzlaff J, Altman DG, PRISMA Group. Preferred reporting items for systematic reviews and meta-analyses: the PRISMA statement. PLoS Med. 2009;6:e1000097.

4. Swaak AJ, Aarden LA, van Statius Eps LW, Feltkamp TE. Anti-dsDNA and complement profiles as prognostic guides in systemic lupus erythematosus. Arthritis Rheum. 1979;22:226-35.

5. Swaak AJ, Nossent JC, Bronsveld W, van Rooyen A, Nieuwenhuys EJ, Theuns $L$, et al. Systemic lupus erythematosus. II. Observations on the occurrence of exacerbations in the disease course: Dutch experience with 110 patients studied prospectively. Ann Rheum Dis. 1989;48:455-60.

6. Mirzayan MJ, Schmidt RE, Witte T. Prognostic parameters for flare in systemic lupus erythematosus. Rheumatol Oxf Engl. 2000;39:1316-9.

7. Tomioka R, Tani K, Sato K, Suzuka C, Toyoda Y, Kishi J, et al. Observations on the occurrence of exacerbations in clinical course of systemic lupus erythematosus. J Med Investig. 2008;55:112-9.

8. El Hachmi M, Jadoul M, Lefèbvre C, Depresseux G, Houssiau FA. Relapses of lupus nephritis: incidence, risk factors, serology and impact on outcome. Lupus. 2003:12:692-6.

9. Petri MA, van Vollenhoven RF, Buyon J, Levy RA, Navarra SV, Cervera R, et al. Baseline predictors of systemic lupus erythematosus flares: data from the combined placebo groups in the phase III belimumab trials. Arthritis Rheum. 2013;65:2143-53.

10. Petri M, Singh $S$, Tesfasyone $H$, Malik A. Prevalence of flare and influence of demographic and serologic factors on flare risk in systemic lupus erythematosus: a prospective study. J Rheumatol. 2009;36:2476-80.

11. Swaak AJ, Groenwold J, Aarden LA, van Statius Eps LW, Feltkamp EW. Prognostic value of anti-dsDNA in SLE. Ann Rheum Dis. 1982;41:388-95.

12. Swaak AJ, Groenwold J, Bronsveld W. Predictive value of complement profiles and anti-dsDNA in systemic lupus erythematosus. Ann Rheum Dis. 1986:45:359-66.

13. ter Borg EJ, Horst G, Hummel EJ, Limburg PC, Kallenberg CG. Measurement of increases in anti-double-stranded DNA antibody levels as a predictor of disease exacerbation in systemic lupus erythematosus. A long-term, prospective study. Arthritis Rheum. 1990;33:634-43.

14. Oelzner P, Abendroth K, Hein G, Stein G. Predictors of flares and long-term outcome of systemic lupus erythematosus during combined treatment with azathioprine and low-dose prednisolone. Rheumatol Int. 1996;16:133-9.

15. Coremans IE, Spronk PE, Bootsma H, Daha MR, van der Voort EA, Kater L, et al. Changes in antibodies to C1q predict renal relapses in systemic lupus erythematosus. Am J Kidney Dis. 1995;26:595-601.

16. Bootsma H, Spronk PE, Ter Borg EJ, Hummel EJ, de Boer G, Limburg PC, et al. The predictive value of fluctuations in IgM and IgG class anti-dsDNA antibodies for relapses in systemic lupus erythematosus. A prospective long-term observation. Ann Rheum Dis. 1997;56:661-6.

17. Ho A, Magder LS, Barr SG, Petri M. Decreases in anti-double-stranded DNA levels are associated with concurrent flares in patients with systemic lupus erythematosus. Arthritis Rheum. 2001;44:2342-9.

18. Abrass CK, Nies KM, Louie JS, Border WA, Glassock RJ. Correlation and predictive accuracy of circulating immune complexes with disease 
activity in patients with systemic lupus erythematosus. Arthritis Rheum. 1980;23:273-82

19. Lloyd W, Schur PH. Immune complexes, complement, and anti-DNA in exacerbations of systemic lupus erythematosus (SLE). Medicine (Baltimore). 1981;60:208-17.

20. Esdaile JM, Abrahamowicz M, Joseph L, MacKenzie T, Li Y, Danoff D. Laboratory tests as predictors of disease exacerbations in systemic lupus erythematosus. Why some tests fail. Arthritis Rheum. 1996;39:370-8.

21. Steiman A, Urowitz MB, Wither JE, Ibanez D, Li T, Gladman DD. Prolonged serologically active clinically quiescent (SACQ) systemic lupus erythematosus (SLE): novel predictors of flare? [Abstract]. Arthritis Rheum. 2010;62(Suppl 10):1874.

22. Cortés-Hernández J, Ordi-Ros J, Labrador M, Buján S, Balada E, Segarra A, et al. Antihistone and anti-double-stranded deoxyribonucleic acid antibodies are associated with renal disease in systemic lupus erythematosus. Am J Med. 2004;116:165-73.

23. Mok CC, Ying KY, Tang S, Leung CY, Lee KW, Ng WL, et al. Predictors and outcome of renal flares after successful cyclophosphamide treatment for diffuse proliferative lupus glomerulonephritis. Arthritis Rheum. 2004;50: 2559-68.

24. Linnik MD, Hu JZ, Heilbrunn KR, Strand V, Hurley FL, Joh T, et al. Relationship between anti-double-stranded DNA antibodies and exacerbation of renal disease in patients with systemic lupus erythematosus. Arthritis Rheum. 2005;52:1129-37.

25. Pan N, Amigues I, Lyman S, Duculan R, Aziz F, Crow MK, et al. A surge in anti-dsDNA titer predicts a severe lupus flare within six months. Lupus. 2014:23:293-8.

26. Hillebrand JJG, Bernelot Moens HJ, Mulder AHL. Changes in Farr radioimmunoassay and EliA fluorescence immunoassay anti-dsDNA in relation to exacerbation of SLE. Lupus. 2013;22:1169-73.

27. To CH, Yu KL, Mok CC. Performance of complement C3, C4 and anti-dsDNA antibody in predicting disease flare in individual organ systems in systemic lupus erythematosus: an analysis of data from 6035 clinical visits [abstract]. Arthritis Rheum. 2011;63(Suppl 10):2296.

28. To CH, Yu KL, Mok CC. Performance of complement C3, C4 and anti-dsDNA antibody in predicting disease flare in systemic lupus erythematosus: an analysis of data from 6035 clinical visits [abstract]. Arthritis Rheum. 2011; 63(Suppl 10):2295.

29. Matrat A, Veysseyre-Balter C, Trolliet P, Villar E, Dijoud F, Bienvenu J, et al. Simultaneous detection of anti-C1q and anti-double stranded DNA autoantibodies in lupus nephritis: predictive value for renal flares. Lupus. 2011;20:28-34.

30. Meyer OC, Nicaise-Roland P, Cadoudal N, Grootenboer-Mignot S, Palazzo E, Hayem G, et al. Anti-C1q antibodies antedate patent active glomerulonephritis in patients with systemic lupus erythematosus. Arthritis Res Ther. 2009;11:R87.

31. Walz LeBlanc BA, Gladman DD, Urowitz MB. Serologically active clinically quiescent systemic lupus erythematosus - predictors of clinical flares. J Rheumatol. 1994;21:2239-41.

32. Hopkins P, Belmont HM, Buyon J, Philips M, Weissmann G, Abramson SB Increased levels of plasma anaphylatoxins in systemic lupus erythematosus predict flares of the disease and may elicit vascular injury in lupus cerebritis. Arthritis Rheum. 1988;31:632-41.

33. Buyon JP, Tamerius J, Belmont HM, Abramson SB. Assessment of disease activity and impending flare in patients with systemic lupus erythematosus. Comparison of the use of complement split products and conventional measurements of complement. Arthritis Rheum. 1992;35:1028-37.

34. Ho A, Barr SG, Magder LS, Petri M. A decrease in complement is associated with increased renal and hematologic activity in patients with systemic lupus erythematosus. Arthritis Rheum. 2001:44:2350-7.

35. Illei GG, Takada K, Parkin D, Austin HA, Crane M, Yarboro CH, et al. Renal flares are common in patients with severe proliferative lupus nephritis treated with pulse immunosuppressive therapy: long-term followup of a cohort of 145 patients participating in randomized controlled studies. Arthritis Rheum. 2002;46:995-1002.

36. Ng KP, Cambridge G, Leandro MJ, Edwards JCW, Ehrenstein M, Isenberg DA. $\mathrm{B}$ cell depletion therapy in systemic lupus erythematosus: long-term followup and predictors of response. Ann Rheum Dis. 2007;66:1259-62.

37. Birmingham DJ, Irshaid F, Nagaraja HN, Zou X, Tsao BP, Wu H, et al. The complex nature of serum C3 and C4 as biomarkers of lupus renal flare. Lupus. 2010;19:1272-80.
38. Viallard JF, Bloch-Michel C, Neau-Cransac M, Taupin JL, Garrigue S, Miossec $V$, et al. HLA-DR expression on lymphocyte subsets as a marker of disease activity in patients with systemic lupus erythematosus. Clin Exp Immunol. 2001;125:485-91.

39. Marto N, Bertolaccini ML, Calabuig E, Hughes GRV, Khamashta MA. Anti-C1q antibodies in nephritis: correlation between titres and renal disease activity and positive predictive value in systemic lupus erythematosus. Ann Rheum Dis. 2005;64:444-8.

40. Siegert CE, Daha MR, Tseng CM, Coremans IE, van Es LA, Breedveld FC. Predictive value of lgG autoantibodies against $\mathrm{Clq}$ for nephritis in systemic lupus erythematosus. Ann Rheum Dis. 1993;52:851-6.

41. Agarwal S, Harper J, Kiely PDW. Concentration of antibodies to extractable nuclear antigens and disease activity in systemic lupus erythematosus. Lupus. 2009;18:407-12.

42. Ng KP, Manson JJ, Rahman A, Isenberg DA. Association of antinucleosome antibodies with disease flare in serologically active clinically quiescent patients with systemic lupus erythematosus. Arthritis Rheum. 2006;55:900-4.

43. Praprotnik S, Bozic B, Kveder T, Rozman B. Fluctuation of anti-Ro/SS-A antibody levels in patients with systemic lupus erythematosus and Sjögren's syndrome: a prospective study. Clin Exp Rheumatol. 1999;17:63-8.

44. Stojan $G$, Fang $H$, Magder L, Petri M. Erythrocyte sedimentation rate is a predictor of renal and overall SLE disease activity. Lupus. 2013;22:827-34.

45. Spronk PE, ter Borg EJ, Limburg PC, Kallenberg CG. Plasma concentration of IL-6 in systemic lupus erythematosus; an indicator of disease activity? Clin Exp Immunol. 1992;90:106-10.

46. Tokano Y, Morimoto S, Kaneko H, Amano H, Nozawa K, Takasaki Y, et al. Levels of IL-12 in the sera of patients with systemic lupus erythematosus (SLE)-relation to Th1- and Th2-derived cytokines. Clin Exp Immunol. 1999;1 16:169-73.

47. Becker-Merok A, Nikolaisen C, Nossent HC. B-lymphocyte activating factor in systemic lupus erythematosus and rheumatoid arthritis in relation to autoantibody levels, disease measures and time. Lupus. 2006;15:570-6.

48. Petri M, Stohl W, Chatham W, McCune WJ, Chevrier M, Ryel J, et al. Association of plasma B lymphocyte stimulator levels and disease activity in systemic lupus erythematosus. Arthritis Rheum. 2008:58:2453-9.

49. Bauer JW, Petri M, Batliwalla FM, Koeuth T, Wilson J, Slattery C, et al. Interferon-regulated chemokines as biomarkers of systemic lupus erythematosus disease activity: a validation study. Arthritis Rheum. 2009; 60:3098-107.

50. Andrade F, Akhter $E_{1}$ Fang $H$, Petri M. Elevated plasma levels of CXCL2 and CXCL10 have distinct predictive value in systemic lupus erythematosus [abstract]. Arthritis Rheum. 2012;64 Suppl 10:619.

51. Rose T, Grützkau A, Hirseland H, Huscher D, Dähnrich C, Dzionek A, et al. IFNa and its response proteins, IP-10 and SIGLEC-1, are biomarkers of disease activity in systemic lupus erythematosus. Ann Rheum Dis. 2013;72:1639-45.

52. Munroe ME, Vista ES, Guthridge JM, Thompson LF, Merrill JT, James JA. Proinflammatory adaptive cytokine and shed tumor necrosis factor receptor levels are elevated preceding systemic lupus erythematosus disease flare. Arthritis Rheumatol. 2014;66:1888-99.

53. Lauwerys BR, Husson SN, Maudoux AL, Badot V, Houssiau FA. sIL7R concentrations in the serum reflect disease activity in the lupus kidney. Lupus Sci Med. 2014;1:e000036.

54. Guthridge JM, Lou R, Kamp S, Munroe ME, Bean K, Macwana SR, et al. THU0046 Predictive modeling of immunologic and inflammatory markers of impending disease flare in patients with systemic lupus erythematosus not taking immunosuppressive medications. Ann Rheum Dis. 2014;73(Suppl 2): 192.

55. Swaak AJ, Hintzen RQ, Huysen V, van den Brink HG, Smeenk JT. Serum levels of soluble forms of T cell activation antigens CD27 and CD25 in systemic lupus erythematosus in relation with lymphocytes count and disease course. Clin Rheumatol. 1995;14:293-300.

56. Spronk PE, Horst G, Van Der Gun BT, Limburg PC, Kallenberg CG. AntidsDNA production coincides with concurrent $B$ and $T$ cell activation during development of active disease in systemic lupus erythematosus (SLE). Clin Exp Immunol. 1996;104:446-53.

57. Spronk PE, ter Borg EJ, Huitema MG, Limburg PC, Kallenberg CG. Changes in levels of soluble T-cell activation markers, slL-2R, SCD4 and SCD8, in relation to disease exacerbations in patients with systemic lupus erythematosus: a prospective study. Ann Rheum Dis. 1994;53:235-9.

58. Miyara M, Mathian A, Haroche J, Arnaud L, Chader D, Musset L, et al. The monitoring of FoxP3 expressing CD4 T cell subsets may be helpful for the 
prediction of systemic lupus erythematosus flares [abstract]. Arthritis Rheum. 2011;63(Suppl 10):658.

59. Landolt-Marticorena C, Prokopec S, Morrison S, Reich H, Scholey J, Gladman $\mathrm{D}$, et al. Fluctuations in SVCAM-1 and adiponectin mirror fluctuations in disease activity in lupus, but cannot be use to accurately predict impending changes in disease state [abstract]. Arthritis Rheum. 2013;65(Suppl 10):2557.

60. Spronk PE, Bootsma H, Huitema MG, Limburg PC, Kallenberg CG. Levels of soluble VCAM-1, soluble ICAM-1, and soluble E-selectin during disease exacerbations in patients with systemic lupus erythematosus (SLE); a long term prospective study. Clin Exp Immunol. 1994;97:439-44.

61. Chan RW-Y, Lai FM-M, Li EK-M, Tam L-S, Chow K-M, Li PK-T, et al. Expression of T-bet, a type $1 \mathrm{~T}$-helper cell transcription factor, in the urinary sediment of lupus patients predicts disease flare. Rheumatol Oxf Engl. 2007;46:44-8.

62. Szeto C-C, Tam L-S, Kwan BC-H, Lai K-B, Wang G, Li EK-M, et al. Monitoring of urinary messenger RNA levels for the prediction of flare in systemic lupus erythematosus. Clin Chim Acta. 2012;413:448-55.

63. Tian S, Li J, Wang L, Liu T, Liu H, Cheng G, et al. Urinary levels of RANTES and M-CSF are predictors of lupus nephritis flare. Inflamm Res. 2007;56:304-10.

64. Rubinstein T, Pitashny M, Levine B, Schwartz N, Schwartzman J, Weinstein E, et al. Urinary neutrophil gelatinase-associated lipocalin as a novel biomarker for disease activity in lupus nephritis. Rheumatol Oxf Engl. 2010;49:960-71.

65. Wisniacki N, Stebbins J, Bienkowska J, Gawlak S, Bennett D, Xiang Y, Dearth A, Ranger A, Burkly L, Petri M. Urinary TWEAK predicts renal disease activity in patients with systemic lupus erythematosus over a 1 year period. Ann Rheum Dis. 2013;72(Suppl 3):474.

66. Schwartz N, Rubinstein T, Burkly LC, Collins CE, Blanco I, Su L, et al. Urinary TWEAK as a biomarker of lupus nephritis: a multicenter cohort study. Arthritis Res Ther. 2009;11:R143

67. Lim KL, Muir K, Powell RJ. Urine neopterin: a new parameter for serial monitoring of disease activity in patients with systemic lupus erythematosus. Ann Rheum Dis. 1994;53:743-8.

68. Michaelson JS, Wisniacki N, Burkly LC, Putterman C. Role of TWEAK in lupus nephritis: a bench-to-bedside review. J Autoimmun. 2012;39:130-42.

69. ter Borg EJ, Horst G, Limburg PC, van Venrooij WJ, Kallenberg CG. Changes in levels of antibodies against the $70 \mathrm{kDa}$ and a polypeptides of the U1RNP complex in relation to exacerbations of systemic lupus erythematosus. J Rheumatol. 1991:18:363-7.

70. Rovin BH, Song H, Hebert LA, Nadasdy T, Nadasdy G, Birmingham DJ, et al. Plasma, urine, and renal expression of adiponectin in human systemic lupus erythematosus. Kidney Int. 2005;68:1825-33.

71. Boekel ET, Prins M, Vrielink G-J, de Kieviet W, Siegert CEH. Longitudinal studies of the association between peripheral CD27++ plasma cells and systemic lupus erythematosus disease activity: preliminary results. Ann Rheum Dis. 2011;70:1341-2.

72. Hanaoka H, Okazaki Y, Satoh T, Kaneko Y, Yasuoka H, Seta N, et al. Circulating anti-double-stranded DNA antibody-secreting cells in patients with systemic lupus erythematosus: a novel biomarker for disease activity. Lupus. 2012:21:1284-93.

73. Bertsias G, loannidis JPA, Boletis J, Bombardieri S, Cervera R, Dostal C, et al. EULAR recommendations for the management of systemic lupus erythematosus. Report of a Task Force of the EULAR Standing Committee for International Clinical Studies Including Therapeutics. Ann Rheum Dis. 2008;67:195-205.

74. Petri M. Disease activity assessment in SLE: do we have the right instruments? Ann Rheum Dis. 2007;66(Suppl 3):iii61-4.

75. Smeenk R, van der Lelij G, Aarden L. Avidity of antibodies to dsDNA: comparison of IFT on Crithidia luciliae, Farr assay, and PEG assay. J Immunol (Baltim Md 1950). 1982;128:73-8.

76. Pisetsky DS. Anti-DNA antibodies—quintessential biomarkers of SLE. Nat Rev Rheumatol. 2016;12:102-10.

77. Wolf BJ, Spainhour JC, Arthur JM, Janech MG, Petri M, Oates JC. Development of biomarker models to predict outcomes in lupus nephritis. Arthritis Rheumatol. 2016;68:1955-63.

78. Banchereau R, Hong S, Cantarel B, Baldwin N, Baisch J, Edens M, et al. Personalized immunomonitoring uncovers molecular networks that stratify lupus patients. Cell. 2016;165:1548-50.

79. van Vollenhoven R, Voskuyl A, Bertsias G, Aranow C, Aringer M, Arnaud L, et al. A framework for remission in SLE: consensus findings from a large international task force on definitions of remission in SLE (DORIS). Ann Rheum Dis. 2017;76:554-61.

\section{Submit your next manuscript to BioMed Central and we will help you at every step:}

- We accept pre-submission inquiries

- Our selector tool helps you to find the most relevant journal

- We provide round the clock customer support

- Convenient online submission

- Thorough peer review

- Inclusion in PubMed and all major indexing services

- Maximum visibility for your research

Submit your manuscript at www.biomedcentral.com/submit 